\title{
The role of intermediaries' power on contracting decision between farmers and intermediaries
}

\author{
Orjon XhoxhI, Remzi Keco*, Engjell Skreli*, Drini Imami*, \\ BarI MusabelLIU*
}

DOI: $10.30682 / \mathrm{nm} 1903 \mathrm{a}$

JEL codes: Q13

\begin{abstract}
The paper investigates the determinants of farmers 'participation in contract farming $(C F)$ in the context of a transition country, namely Albania. The focus is on intermediaries'bargaining power effect on farmers' engagement in CF. Exploratory factor analysis is used to develop measures for the latent variables, while a logit regression model is employed to test the hypothesized relationship. The results show that intermediaries' bargaining power moderates negatively the relationship between farmers' specific investments and CF participation. Farmers' with high specific investment are reluctant to contract with buyers who have power because contracting with such a buyer implies that they can extract higher values from farmers'specific investments. Other strong predictors of contracting decision are farmers' trust on the intermediary, intermediary's advice to the farmer and intermediary's specific investment.
\end{abstract}

Keywords: Contract farming, Intermediaries' power, specific investments, farmers 'trust, Albania.

\section{Introduction}

Contract farming (CF) in the context of developing countries has received considerable attention both from practitioners and researchers. One of the reasons to such degree of popularity is that contract farming is a mechanism that helps farms to commercialise their products, which then lead to higher incomes for small farmers, increased productivity, modernization of the agricultural sector and development of these countries (Goldsmith, 1985; Key and Runsten, 1999; Maertens and Swinnen, 2009; Miyata et al., 2009; Bellemare, 2012). A number of authors (Grosh, 1994; Key and Runsten, 1999;
Katchova and Miranda, 2004) have argued that $\mathrm{CF}$ is an institutional solution to problems of market failures in the markets of insurance, information and credit. As a result, this form of relationship governance solves a number of productivity constrains for small farmers including reduced market risks, access to credit, inputs and information.

On the other hand, Ton et al. (2018) finds from a meta-analysis of 22 studies on CF, that poor farmers in terms of land and assets are rarely included in CF. Considering the ex-ante and expost transaction cost (i.e. searching, negotiating, monitoring, etc.) that a buyer incurs to contract with a farmer, the buyer will have a strong in-

* Agricultural University of Tirana, Albania. Corresponding author: oxhoxhi@ubt.edu.al 
centive to contract with a small number of large farmers than with several small farmers because the transaction cost in the second case would be much higher. If this would be the case, then small farmers would have no option but to move out of agriculture and their lands will be reallocated towards a few big commercial farms, thus increasing rural inequality (Korokvin, 1992; Little and Watts, 1994; Singh, 2002). Furthermore, in the debate on $\mathrm{CF}$ is highlighted that large buyers (i.e. agro-industrial firms, exporters, etc.) could exploit small farmers due to their bargaining power. As a result, they could make farmers overly dependent on them by affecting their production and investment pattern. In such a case, farmers will face limited exit options (i.e. lockin situation) which may force them to accept less favourable contract terms (Sivramkrishna and Jyotishi, 2008).

In view of, the role that intermediaries' bargaining power plays in affecting farmers business and livelihood, risk and profit sharing, it becomes imperative to understand its effects on contracting decisions between farmers and intermediaries. There has been limited research that has examined the effects of intermediaries' bargaining power on contracting decisions with farmers. In addition, here power is viewed from the bargaining power lens, which is more effective in explaining complex relations compared to market power theory (Sexton, 2013; Sorrentino, Russo and Cacchiarelli, 2018). Therefore, the main objective of this study is to investigate how the intermediaries' bargaining power affects $\mathrm{CF}$ in the greenhouse tomatoes sector in Albania, which is characterized by small scale farming.
The rest of the paper is structured as follows. Section 2 presents briefly greenhouse tomatoes sector in Albania, followed by a review of the literature on $\mathrm{CF}$ in section 3 , which also outlines the study hypothesis. Section 4 describes the methodology. While, section 5 provides results and discussion and section 6 concludes the paper.

\section{Greenhouse tomatoes sector in Albania}

Albania has strong tradition and potential in the production of field and greenhouse vegetable, due to suitable climate and low labour cost. Production of vegetables, particularly greenhouse vegetables has increased significantly in the last years. The bulk of production is addressed to the domestic market. Vegetables are important in the Albanian food diets and among them tomato is the most important item - Albania ranks as one of the countries with highest consumption per capita of tomatoes (Skreli et al., 2017).

Most tomatoes are produced in greenhouse and more than half of the total greenhouse area is cultivated with tomatoes. The production of field tomatoes is common in all regions of Albania, while production of greenhouse tomatoes is concentrated in the region of Lushnja and Berat (where also the survey was focused), one of the most productive areas in Central Albania (Skreli et al., 2017).

The increasing competitiveness of Albanian fresh vegetables is confirmed by the trade balance (Table 1). A key role in this change of the trade balance is played by fresh tomatoes (mainly greenhouse tomatoes), which makes most of the trade surplus. Production of tomatoes has

Table 1 - Tomatoes supply balance (Mt).

\begin{tabular}{|l|r|r|r|r|r|r|r|}
\hline & \multicolumn{1}{|c|}{2000} & \multicolumn{1}{c|}{2005} & \multicolumn{1}{c|}{2010} & \multicolumn{1}{c|}{2011} & \multicolumn{1}{c|}{2012} & \multicolumn{1}{c|}{2013} & \multicolumn{1}{c|}{2014} \\
\hline Production & 162,000 & 152,000 & 199,283 & 200,000 & 205,000 & 226,220 & 234,150 \\
\hline Exports & 24 & 123 & 6,573 & 11,349 & 17,315 & 25,245 & 32,992 \\
\hline Imports & 2,263 & 6,514 & 3,429 & 3,061 & 3,080 & 2,615 & 2,621 \\
\hline Domestic supply & 164,239 & 158,391 & 196,139 & 191,712 & 190,765 & 203,590 & 203,779 \\
\hline Import/supply & $1.38 \%$ & $4.11 \%$ & $1.75 \%$ & $1.60 \%$ & $1.61 \%$ & $1.28 \%$ & $1.29 \%$ \\
\hline Export/production & $0.01 \%$ & $0.08 \%$ & $3.30 \%$ & $5.67 \%$ & $8.45 \%$ & $11.16 \%$ & $14.09 \%$ \\
\hline
\end{tabular}

Source: INSTAT (production), UNSTAT (trade). 
grown fast over the years, while exports have increased even more, significantly exceeding imports.

Given the potential for growth, vegetable including tomato has been considered a priority sector by the Albanian government to target for the period 2014-2020 (MARDWA, 2014). The continuous increasing levels of production (caused by investments in new greenhouses), can be addressed through increased levels of exports, and through targeting higher end segments. So far, most exports target neighbouring Western Balkan countries - exports to Western EU countries are negligible due to gaps in standardization and standards compliance, caused by high level of production fragmentation. Supermarket chains in EU require compliance with safety and quality standards and big volumes which can only be achieved through better coordination in the value chain. Therefore, there is a need to have a better understanding about the forms of relations (and coordination) in the value chain, their determinants and implications.

\section{Literature review on contract farming}

Contract farming (CF) generally refers to «agricultural production carried out according to an agreement between a buyer and farmers, which establishes conditions for the production and marketing of a farm product or products» (FAO, 2013). The literature points out that $\mathrm{CF}$ lies somewhere in between spot market transaction and vertical integration and it combines the advantages of both strict quality control, high coordination (vertical integration) flexibility and lower specific investment (spot market transaction).

The empirical research on $\mathrm{CF}$ is quite rich and could be divided into two main streams: 1) the determinants of participation in $\mathrm{CF}$ and 2) the impact of CF to on an outcome such as on farmers' income, food security, risk mitigation (Bellemare, 2012; Bellemare and Novak, 2017; Ton et al., 2018; Saqib et al., 2018) and the most recent on different sources of farms income (Bellemare, 2018). The focus here is only on the former point. By abstracting from empirical research, a number of theories have been used to shed light on CF, some of these theories are; the life cycle theory, transaction cost economics, contract enforcement, and competency/capability theories. While there are several theories that have been used to explain $\mathrm{CF}$ (see Prowse, 2012), the most developed body of work is transaction cost economics. David and Han (2004) highlights that TCE has become one of the leading theoretical perspectives in the study of governance arrangements of trading relationships (i.e. spot market, contracting and vertical integration). Based on the work of Coase (1937), Williamson $(1975,1981)$ developed the TCE framework, which emphasizes that the decision on how to govern a relationship is principally determined by differences in transaction cost. Williamson $(1975,1981)$ demonstrated, how specific investments, uncertainty and transaction frequency relate to transaction costs. The fundamental tenets of TCE theory is that firms will tend to integrate in the presence of high uncertainty, large specific investments and frequent transactions. The reason being that under these circumstances the transaction costs are higher in trading relationships governed by spot market transaction then in hierarchies (i.e. vertical integration or contracting). In the same line, empirical research on CF points out that poorer farmers are less likely to engage in CF (Ton et al., 2018; Saqib et al., 2018). In addition, Minot (2007, p. 1) outlines that since contracting involves costs, «it is economically justifiable only when the buyer is a large firm (a processor, exporter, or supermarket chain)». In this context, the following propositions are made:

Hypothesis 1: Farmers'specific investment is positively related to contract farming.

Hypothesis 2: Intermediaries' specific investment is positively related to contract farming.

On the other hand, contract enforcement theories focus on the incentives to honor contracts (Klein, 1996). These incentives can be public (such as forms of legal redress), private (the match between the contents of the contract and market conditions at the time of exchange), or a mixture of both. Gow et al. (2000) posit that at any point in time during a contract, both parties assess the costs and benefits of breaking their 
deal. If market conditions change unexpectedly, such that the benefits of delaying or breaking the contract are greater than the capital and reputation losses for one party, then this will lead to a "holdup" (in other words, exchange will be delayed and the contract will not be honored). Conversely, if the benefits estimated from such unexpected changes do not exceed the capital and reputation losses, then the contract will be fulfilled. In the context of this study some of the concepts that could be related to this theory are farmers' trust in the intermediary and intermediaries' advice to the farmer. Both variables are a form of private incentives, when the match between market conditions are better than contract terms both of them should be lower and when the match is right, they should show higher levels. Following this perspective, the hypotheses that are raised are:

Hypothesis 3: Farmers' trust on the intermediary is positively related to contract farming. Hypothesis 4: Intermediaries' advice to the farmers is positively related to contract farming.

In the scientific debate on CF a number of authors point out that $\mathrm{CF}$ could be a mechanism that large buyers (i.e. agro-industrial firms, exporters, etc.) could use to exploit small farmers due to their power. As a result of their power, they could make farmers overly dependent on them by affecting their production and investment pattern. Thereby, farmers will face limited exit options (i.e. lock-in situation) which may force them to accept less favorable contract terms (Sivramkrishna and Jyotishi, 2008). It could be argued that when farmers' trade with large buyers that possess high bargaining power would be reluctant to engage in $\mathrm{CF}$ with them due to "fear" of exploitation. In the authors' view intermediaries' power works as a moderator of the relationship farmer specific investment and contracting decision, which based on TCE theory is positive. In this view, farmers with large specific (e.g. farm size) have lower incentives to contract with intermediaries with high power because the latter one could extract higher value/rents from farmers' investment. Thus, the proposition that is derived from this is that:
Hypothesis 5: In the presence of high intermediaries' bargaining power the association between the farmer specific investment and contract farming is weaker.

The concept of power in food value chains is mainly studied as market power and bargaining power. Here the focus is on bargaining power, which is conceptualised as a party ability «...to obtain a concession from another party by threatening to impose a cost, or withdraw a benefit, if the party does not grant the concession» (Kirkwood, 2005). Thus, as pointed out by Sorrentino et al. (2018) in bargaining power models one can account for contracting elements such as risk allocation, product quality, payment delays, inputs financing, provision of services. Whereas, these elements are not analyzed in market power theory, which focuses primary on prices and quantities. In the context of this study, focusing on intermediaries' bargaining power is more appropriate than analyzing their market power, which would not achieve to explain why farmers enter into a contracting relationship.

Regarding the direct effect of intermediaries' power on CF, no proposition is made because possessing bargaining power gives options to the firm in its contracting decision. Precisely which options make sense cannot be selected until transaction costs among other factors are considered (Shervani et al., 2007). Furthermore, in this study intermediaries' power is considered as its total power (i.e. the sum of the scores of its underlining dimensions). However, considering that intermediaries' power over farmers is multidimensional (see Xhoxhi et al., 2014) the effect that one dimension might have on CF could be in opposite direction to the effect of another dimension.

Another issue that is related to intermediaries' power is information asymmetry. In the debate on $\mathrm{CF}$, it is generally argued that intermediaries could take advantage of farmers' weak position by paying low prices due to information asymmetry. Thus, more informed farmers could evaluate and understand the benefits of a contracts better than non-informed farmers. Following this point, the hypothesis that arises is: 
Hypothesis 6: Farmers' access to market information is positively related to contract farming.

Hypothesis 7: Government extensions services advice to the farmers is positively related to contract farming.

So far the discussion was focused on some of the theories used to explain $\mathrm{CF}$, on the other hand, the empirical research on $\mathrm{CF}$ points out that, the factors affecting participation in $\mathrm{CF}$ can be divided into five groups: 1) demographic factors (age, sex, family size, education and training in agriculture), 2) operational factors (farm size, specific assets, farmer experience, specialization, risk preferences, and access to resources (i.e. credit, storage, information)), 3) market factors (price fluctuation, demand stability and distance to the market), 4) environmental factors (promoting policy, and local economic and social development level) and relational norms (long term orientation, trust and commitment) (Morgan and Hunt, 1995; Masakure and Henson, 2005; Miyata et al., 2009; Bellemare, 2012; Ton et al., 2018; Saqib et al., 2018). However, the results of empirical research don't come to a consensus regarding the sign and significance of a number of factors on contract participation. For example, education is often included in $\mathrm{CF}$ studies but the results regarding its effects are mixed, from significantly positive (Arumugam et al., 2011) to significantly negative (Miyata $e t$ al., 2009) or no effect/insignificant (Bellemare, 2012; Ito et al., 2012). According to Wang et al.
(2014) the heterogeneity of results could be attributed to institutional differences across countries and across commodities. The results of Simmons, et al. (2005) provide evidence that the significance of a factor on contract participation depends on commodity.

\section{Methodology}

\subsection{Data collection and sample characteristic}

Data for the current research come from e structured survey which took place during November-December 2016 in the most productive greenhouse vegetables area in Albania, namely in Berat and Lushnja. The sample frame consists of 242 famers which were randomly selected and interviewed by well-trained graduate students. The margin of error based on current sample size is 6.3 with a $95 \%$ confidence interval. The questionnaire was designed to operationalize the constructs discussed in Table 5.

The average age of household head $(\mathrm{HH})$ engaged in greenhouse tomato production is 43.9 years and included in the interval between 20 and 67 years old (Table 2). Farmers are characterised by low education level as supported by a median of 2 corresponding to lower secondary education (9 years of education); famers with no education and university diploma are also represented in the sample. Farming is the main employment for the majority of farmers in the sample as shows by a median of 4 ; these farm-

Table 2 - Socio-economic characteristics of study sample.

\begin{tabular}{|l|c|c|c|c|c|}
\hline & Mean & Median & Std. Dev & Min. & Max. \\
\hline Age & 43.9 & 45 & 11.8 & 20 & 67 \\
\hline Education* & $\mathrm{Na}$ & 2 & $\mathrm{Na}$ & 1 & 5 \\
\hline Main employment for Head** & $\mathrm{Na}$ & 4 & $\mathrm{Na}$ & $\mathrm{Na}$ & \\
\hline Experience in farming (years) & 17.1 & 20 & 10.1 & 1 & 48 \\
\hline Experience in tomato cultivation (Years) & 8.1 & 5.5 & 6.3 & 1 & 26 \\
\hline Total area (Dynym) & 14.5 & 12 & 11.4 & 0.5 & 100 \\
\hline Area under greenhouse tomato (Dynym) & 2.8 & 2 & 2.3 & 0.5 & 18 \\
\hline
\end{tabular}

* Education: 2 corresponds to lower secondary education (9 years of education), 1 corresponds to no education and 5 corresponds to university diploma; ${ }^{* *}$ Main employment of head: 4 corresponds to self-employment in own farm. 
ers have on average 17.1 years of experience in farming and 8.1 years of experience in cultivation of greenhouse tomato. The average farm size is 14.5 dynyms $(1.45 \mathrm{Ha})$ which represents adequately the farm size in Albanian (about 1.2 Ha according to MARDWA (2014)), and the average area under greenhouse cultivation is 2.8 dynym $(0.28 \mathrm{Ha})$.

\subsection{Measurement development}

In order to test the hypotheses outlined above, it is necessary to develop measures of the variables of this study. One of the main determinants proposed to affect the contracting decision is intermediaries' power. Based on the literature of power in marketing channels it appears that channel members power is associated with trading parties' perception. Bacharach and Lawler (1981b) look at power between parties in a negotiation process and claim that negotiation power is perceived power. Furthermore, they point out that meaningful power in a business relationship does not exist beyond the parties' perceptions of power. March (1955) suggested that attributed influence be used to measure power directly. $\mathrm{He}$ also suggests capturing the opinion change due to the influence through the use of likert scale measures. There are several studies of power in marketing channels (El-Ansary and Stem, 1972; Hunt and Nevin, 1974; Etgar, 1978; Lusch and Brown, 1982; Collins, 2002 and 2007, Xhoxhi et $a l ., 2014)$ that have used perception of channel members to derive a measure of power. Therefore, the measure of power in this study is derived from farmers' perception of intermediaries' power over them.

To derive measures of power, nine activities important to farmers' business were chosen based on a series of semi-structured interviews with farmers, literature review and discussions with key informants of the supply chain. These activities were: pesticides selection, fertilizer selection, variety selection, the way the product is harvested, the time when it is harvested, the way it delivered, price to the intermediary, payment terms of the intermediary, and total payment of the intermediary. The extent of intermediary's influence was captured for each activity by using a five-point Likert scale, ranging from 1 (no influence) to 5 (major influence). To get our measure of power, the level of intermediary's' influence for each activity was multiplied by a weight of the perceived level of importance of each activity to the farmer. This level of importance of each activity to the farmer was also measured using a Likert scale (1 no importance to, 5 major importance). The main reason of multiplying the influence level by the importance of the activity to the farmer was to get the directional element of power. Power is not just influence, it is influence in a direction that favours the one who exercised it (intermediary) but in this direction, the one on whom power was exercised over (farmer) would not have freely tended. In this context, one can exercise influence without exercising power. This method of deriving a measure of the power variable was used by El-Ansary and Stern (1972), Butaney and Wortzel (1988), Collins (2002 and 2007).

Beside intermediaries' power other variables that are part of the hypothesis of the study and measured with likert scale are farmers' trust on the intermediary, intermediary's advice to the farmer, farmers' access to information and government extension services advice. In order to develop measures for these variables, all the items representing them are entered in an Exploratory Factor Analysis (EFA).

As it is shown in Table 3, the EFA using principal component applied to the items of the variables presented above, revealed 7 factors from which three dimensions of intermediaries' power over farmers' activities. These 7 factors explain the structure of the data set accounting for $66.6 \%$ of the total variation. Barlett's test of sphericity $\left(\chi^{2}=1682: \mathrm{df}=231 ; \mathrm{P}<.000\right)$ and the KMO test of sampling adequacy (.727) confirm the appropriateness of the factor analysis (Field, 2009). While it is possible to extract as many factors as there are items, it was decided to extract only those factors that fulfilled the Kaiser's criterion for factor retention. Kaiser (1960) recommended retaining all factors with eigenvalues greater than one. All factor loadings are well in excess of Stevens (2002) recommended value of .40 , providing evidence of constructs convergent validity. Factor 1 (F1) represents farmers' 
Table 3 - Exploratory factor analysis.

\begin{tabular}{|c|c|c|c|c|c|c|c|c|}
\hline & $\alpha$ & $F 1$ & $F 2$ & $F 3$ & $F 4$ & $F 5$ & F6 & $F 7$ \\
\hline $\begin{array}{l}\text { F1) Farmers' trust on buyer } \\
\text { Promises made by the intermediary are } \\
\text { credible. } \\
\text { I believe the information that the intermediary } \\
\text { gives me regarding market prices. } \\
\text { I trust the intermediary. } \\
\text { The intermediary is not always honest with } \\
\text { me (R). }\end{array}$ & 0.813 & $\begin{array}{l}0.854 \\
0.813 \\
0.756 \\
0.499\end{array}$ & & & & & & \\
\hline $\begin{array}{l}\text { F2) Framers' access to information } \\
\text { How much access do you have to get the } \\
\text { necessary information to identify market } \\
\text { opportunities? } \\
\text { How much access do you have to get } \\
\text { the necessary information to understand } \\
\text { intermediaries' needs? } \\
\text { How much access do you have to get the } \\
\text { necessary information about prices? } \\
\text { How much access do you have to get the } \\
\text { necessary information about required } \\
\text { product quality? }\end{array}$ & 0.769 & & $\begin{array}{l}0.789 \\
0.766 \\
0.757 \\
0.67\end{array}$ & & & & & \\
\hline $\begin{array}{l}\text { F3) Power over input selection } \\
\text { Power Pesticides } \\
\text { Power Fertilizer } \\
\text { Power Variety }\end{array}$ & 0.702 & & & $\begin{array}{l}0.795 \\
0.782 \\
0.736 \\
\end{array}$ & & & & \\
\hline $\begin{array}{l}\text { F4) Power over activities related to product } \\
\text { quality } \\
\text { Power Way Harvest } \\
\text { Power Way Delivery } \\
\text { Power Time Harvest }\end{array}$ & 0.702 & & & & $\begin{array}{l}0.824 \\
0.702 \\
0.659\end{array}$ & & & \\
\hline $\begin{array}{l}\text { F5) Intermediary's advice to the farmer } \\
\text { How often do you get advised by the } \\
\text { intermediary about market demands? } \\
\text { Has the intermediary provided you with } \\
\text { appropriate advices, so that you produce } \\
\text { products fitting the required standard? } \\
\text { How often do you get advised by the } \\
\text { intermediary about the cultivation technology? }\end{array}$ & 0.677 & & & & & $\begin{array}{l}0.776 \\
0.723 \\
0.682\end{array}$ & & \\
\hline $\begin{array}{l}\text { F6) Power over margin } \\
\text { Power Amount to be Paid } \\
\text { Power Agreement terms } \\
\text { Power Price }\end{array}$ & 0.665 & & & & & & $\begin{array}{l}0.861 \\
0.764 \\
0.618 \\
\end{array}$ & \\
\hline $\begin{array}{l}\text { F7) Government extensions advice } \\
\text { How often do you get consoled by the } \\
\text { government extension about market demands? } \\
\text { How often do you get consoled by the } \\
\text { government extension about the cultivation } \\
\text { technology? }\end{array}$ & 0.705 & & & & & & & $\begin{array}{l}0.848 \\
0.814\end{array}$ \\
\hline
\end{tabular}

Note: Extraction Method: Principal Component Analysis. Rotation Method: Varimax with Kaiser Normalization. ${ }^{1}$ Factors are highlighted in bold. 
trust on the intermediary, F2 farmers' access to information, F3 intermediaries' exercised Power Over farmers' Input selection activities (POI), F4 represents intermediaries' exercised Power Over farmers' activities that contribute to product Quality (POQ), F5 intermediaries' advice to the farmer, F6 intermediaries' exercised Power Over farmers' Margin related activities (POM) and $\mathrm{F} 7$ government extension services advice. The Chronbach's $\alpha$ value for all constructs (except intermediaries' power over margin and intermediaries' advice to the farmer) exceeds the cut-off value of .70 , giving evidence of constructs reliability (Nunally, 1981). For the two variables that have Chronbach's $\alpha$ value lower than .70 , they are still considered because they are above the minimum accepted value of .60 and the items pertaining to these variables group together very strongly. Lastly, to get the measures of each variable, composites were generated from the EFA using the regression method. To get a measure of intermediaries' total power, the sum of the scores of al dimension was taken.

Before proceeding with the hypothesis testing, another issue that needs to be discussed regarding the development of measures with good psychometric properties is that of construct discriminant validity. A construct is considered valid when it fulfils not only the condition of convergent validity (items loading significantly on the factor they are measuring) but also the discriminant validity one (ensuring that these factors are distinct and do not covary highly) (Bagozzi et al., 1991). Exploratory factor analysis gives some evidence of discriminant validity, when items load strongly only on one factor (i.e. there are no cross loadings where the difference is bigger than .20) (Gaskin, 2016). As the results of Table 3 show all items load only on one factor and there are no cross loadings bigger than 0.20.

\subsection{The model}

In general, the study of the determinants of $\mathrm{CF}$ is examined by employing a probit or logit regression where the dependent variable is a binary choice between spot market transaction and CF (Masakure and Henson, 2005; Zhu and Wang, 2007). Therefore, a logit regression is used to test the hypothesis outlined in section three because the dependent variable contracting decision is a dummy variable. It should be noted that the variable was composed of three categories 1 - no agreement, 2 - verbal agreement and 3 - written contract. Considering that very few observations were on written contracts it was decided to merge the verbal agreement with written contracts together. In addition, the qualitative research showed that written contracts were very similar to verbal agreements. In both types, the parties focus was to agree on selling/buying the production prior to harvest time. Thus, merging both categories should not affect the results ${ }^{1}$.

\section{Discussion of the results}

The results of the logit regression are presented in Table 4, while Table 5 shows a summary of the variables of the model, including their operationalization and the hypothesis relating each independent variable to the dependent one. Regarding model diagnostics only four cases have standardised residuals bigger than two. From the inspection of the cook's values there is no case with a value bigger than one. Therefore, it can be concluded that the model fits the data fairly well.

As the Table 4 shows the raised hypothesis are partially supported. Intermediary's specific investments have a positive effect on contracting decision but only at $10 \%$ level of significance. The finding is consistent with TCE theory. Following the TCE perspective Minot (2007) outlines that since contracting involves costs, it is economically justifiable only when the buyer is a large firm (a processor, exporter, or supermarket chain). On the other hand, farmers' specific investment (i.e. farm size) has no significant effect on contracting decision.

Farmers' trust on intermediary appears to be a strong predictor of farmers' decision to engage in CF. The result converges with the theory of trust and other empirical research on trust

\footnotetext{
${ }^{1}$ A separate logit regression only with data on verbal agreement was run, and the results are in the same line as the one in table four.
} 
Table 4 - Logit regression: Dependent Variable Contracting Decision.

\begin{tabular}{|c|c|}
\hline & $\begin{array}{c}\text { Dependent } \\
\text { variable: }\end{array}$ \\
\hline & Contracting \\
\hline Farmers' Age & $\begin{array}{c}-0.029^{* *} \\
(0.015)\end{array}$ \\
\hline No family member $>18$ & $\begin{array}{l}-0.094 \\
(0.120) \\
\end{array}$ \\
\hline Farmers' education & $\begin{array}{l}-0.091 \\
(0.285)\end{array}$ \\
\hline Farmers' trust on intermediary & $\begin{array}{c}0.926^{* * *} \\
(0.183)\end{array}$ \\
\hline Farmers' access to information & $\begin{array}{c}0.269 \\
(0.167) \\
\end{array}$ \\
\hline Intermediary' advice to farmer & $\begin{array}{c}0.439 * * * \\
(0.163) \\
\end{array}$ \\
\hline Gov Extension advice to farmer & $\begin{array}{c}0.097 \\
(0.198) \\
\end{array}$ \\
\hline Intermediary specific investment & $\begin{array}{l}0.769^{*} \\
(0.432) \\
\end{array}$ \\
\hline Farm size & $\begin{array}{c}0.022 \\
(0.017) \\
\end{array}$ \\
\hline Intermediary' total power & $\begin{array}{c}0.951^{* * *} \\
(0.215) \\
\end{array}$ \\
\hline $\begin{array}{l}\text { Farm size } * \text { Intermediary } \\
\text { total power }\end{array}$ & $\begin{array}{l}-0.025^{* *} \\
(0.011) \\
\end{array}$ \\
\hline Constant & $\begin{array}{c}1.278 \\
(1.000) \\
\end{array}$ \\
\hline $\begin{array}{l}\text { Observations } \\
\text { Log Likelihood } \\
\text { Akaike Inf. Crit. }\end{array}$ & $\begin{array}{c}225 \\
-114.722 \\
253.443\end{array}$ \\
\hline
\end{tabular}

Note: ${ }^{*} p<0.1 ;{ }^{*} p<0.05 ;{ }^{* * *} p<0.01$;

Cox \& Snell $R^{2}=.305 ;$ Nagelkerke $R^{2}=.407$,

Model Chi-Square $=81.7$.

(Morgan and Hunt, 1994). Trust is viewed as an important element for sustainable relationships (Macneil, 1980). Relationships and contracts that are not based on trust, have a higher likelihood to default. Benmehaia and Brabez (2018) report high levels of contractual default from the processing tomatoes sector in Algeria, due to weak incentives provided by the buyer (specifically related to price). Swinnen (2016) points out that contract can create surplus in high standards production and small farmers can capture a significant part of this surplus if their holdup opportunities create incentives for the intermediary to pay the farmer a premium as part of the contract. On the other hand, Fernández-Olmos and Vinuesa (2009) argues that processors should choose the mechanism that maximizes their profits, suggesting that offering price incentives does not lead always to higher profits. In this view, for a buyer to develop successful contracts/relationships trust needs to be built, which is highly influenced by the provision of incentives (not necessarily price based - could be services such as pre-financing of inputs, technical assistance). Though, the value generated from such contracts should outweigh the cost of establishing them. Consequently, it can be argued that trust development is a costly process but it's a mechanism that mitigates uncertainties (Ring and Van de Ven, 1992) increasing transaction efficiency and also improves overall trading relationship performance.

Intermediary's advice to the farmer could be an instrument (not price based) to build trust and reduce the risks of contractual defaults. The study result show that advice provided by intermediaries, positively affect farmers' decision to participate in CF. The rational here is that the more information the intermediary provides to the farmer about the market (e.g. variety required, product standards, prices, market potential) the better the farmers' decision. Over repeated exchanges information is attained, leading to the development of trust, which helps the decision-making process on making informed choices, about with whom to contract or not contract (Poppo and Zenger, 2002). Benmehaia and Brabez (2018) argue that closer coordination between farmers-processors in terms of technical assistance would help farmers achieve higher yields, which they find to be positively associated with farmers' participation in CF. It would be interesting for future research to look at the mediation effect of trust on the intermediary's advice (or technical assistance offered by the intermediary) to the farmer and contracting decision. This should shed more 
Table 5 - Summary of variables in the logit model.

\begin{tabular}{|c|c|c|c|}
\hline & Variables & Operationalization & Hyp \\
\hline DV & Contracting decision & Dummy -0 spot market VS 1 verbal/written agreement & \\
\hline $\mathrm{CON}$ & No family member $>18$ & Continuous - number of family member $>18$ years of age & - \\
\hline $\mathrm{CON}$ & Farmers' Education & Continuous - number of years of education & - \\
\hline $\mathrm{CON}$ & Farmers' Age & Continuous & - \\
\hline IV & $\begin{array}{l}\text { Farm size (farmer } \\
\text { specific investment) }\end{array}$ & Farm surface area in dynyms (1/10 ha) & $\mathrm{H} 1 \mathrm{x}$ \\
\hline IV & $\begin{array}{l}\text { Intermediary specific } \\
\text { investment }\end{array}$ & $\begin{array}{l}\text { Dummy variable where } 1 \text { buyers with low specific investment } \\
\text { (e.g. local trader) VS } 2 \text { intermediary with high specific } \\
\text { investment (e.g. exporters) }\end{array}$ & $\mathrm{H} 2 \checkmark$ \\
\hline IV & $\begin{array}{l}\text { Farmers' Trust on } \\
\text { intermediary }\end{array}$ & EFA composite - from likert scale items & $\mathrm{H} 3 \checkmark$ \\
\hline IV & $\begin{array}{l}\text { Intermediary' advice to } \\
\text { farmer }\end{array}$ & EFA composite - from likert scale items & $\mathrm{H} 4 \checkmark$ \\
\hline IV & $\begin{array}{l}\text { Farm size * Intermediary } \\
\text { total power }\end{array}$ & Interaction effect & H5 $\checkmark$ \\
\hline IV & $\begin{array}{l}\text { Farmers' access to } \\
\text { information }\end{array}$ & EFA composite - from likert scale items & H6x \\
\hline IV & Intermediary' total power & EFA composite - from likert scale items & \\
\hline IV & $\begin{array}{l}\text { Gov Extension advice to } \\
\text { farmer }\end{array}$ & EFA composite - from likert scale items & $\mathrm{H} 7 \mathrm{x}$ \\
\hline
\end{tabular}

Note: DV-Dependent variable; CON - Control variable; $I V$ - independent variable of interest; $x$ - hypothesis not supported; $x$ - hypothesis not supported with result in opposite direction and significant; $\checkmark$-hypothesis supported.

light on the trust development process between farmers and intermediaries and on the indirect effect that intermediary's advice has on contracting decision through trust.

Study results point out that the moderation effect of intermediaries' bargaining power on the association between farmer's specific investment and farmers' participation in $\mathrm{CF}$ is negative. In other words, intermediaries' bargaining power weakens the association between farmers' specific investments and CF participation. Thus, big farmers (i.e. farmers with high specific investments) are more reluctant to establish contracts with buyers that possess substantial bargaining power because they can "extract" more rent from their investment. On the other hand, the moderation effect of intermediaries' bargaining power does not suggest that small farmers (i.e. low specific investments) would be less likely to engage in a contractual relation with a "strong buyer", on contrary they would tend to participate in such contracts. As argued by Benmehaia and Brabez (2018) small scale farmers are more likely to contract because they are more risk-averse and place more value on contracts as a risk reduction mechanism. Our results add another critical point in understanding farmers' behaviour towards participation in $\mathrm{CF}$, by pointing out that the loss of rent from a specific investment for small farmers is much lower than that of a large one. Therefore, it is not only the behaviour towards risk but also the rent that is at stake from a specific investment that determines farmers' participation in CF arrangement.

The direct effect of intermediaries' bargaining power on contracting decision is positive and significant. However, this might not be the case for other sectors or other products because bargaining power gives alternatives with whom to contract. Yet, selecting which alternative is the 
most optimal is not decided until transaction costs among other factors are considered. Thus, future research might look into this relationship for other sectors. Furthermore, instead of looking only at the intermediaries' total bargaining power effect on CF participation, it would be interesting to investigate the effects of the different intermediaries' power dimensions on the contracting decision.

Farmers' access to information, government extension services advice to the farmer do not appear to have any significant effect on farmers' engagement in CF. On the other hand, the control variable used in the model, farmers' age is negatively related to CF. In the literature of $\mathrm{CF}$, concerns are raised that $\mathrm{CF}$ might leave out small farmers from food supply chains, yet we fail to find any effects of farm size on contracting decision. In addition, it appears that farmers' education has no effect on contract participation.

\section{Conclusions}

Previous work has linked intermediaries' power to several aspects of farmers' intermediaries trading relationship. Yet, there is a gap in the literature on how the intermediaries' bargaining power affects contracting decision between farmers and intermediaries. This study attempts to fill this gap by providing insight on the effect of intermediaries' power on contracting decision from the tomatoes greenhouse sector in Albania.

The research found that intermediary's specific investment affects positively farmers' participation in CF. Yet, the moderating effect of intermediaries' power on the farmers' specific investment to $\mathrm{CF}$ participation is negative and significant. This result leads to the conclusion that farmers would be reluctant to contract with buyers that have high power, even when they have made high specific investment because contracting or trading with such buyer means that they can extract higher rent from farmers' specific investments than buyers with low power. Consequently, the size of the rent of a specific investment that is at stake explains farmers behaviour' towards engagement in CF. Thus, a farmer's decision on relationship governance mode selection is a function not only of his risk-aversion level but also of the specific investment rent that is at stake.
Farmers' trust in the intermediary is found as a strong predictor of contracting in the greenhouse vegetables value chain. It appears that trust development is costly, nevertheless it is a mechanism that mitigates uncertainties leading to increased transaction efficiency and better performing relationships. As a result, an intermediary ought to weight the cost associated with building trust (i.e. price incentives, technical assistance) versus the benefits of relationships embedded in trust (i.e. lower contractual defaults, reduced monitoring costs, improved relationship performance). In the authors' view, in developing or transition countries where formal mechanisms of arbitration are deficient, a buyer would be better-off to develop trust with farmers, otherwise the losses and uncertainty would be higher than the cost of trust building. Thus, provision of advice (i.e. technical assistance) to the farmer could be an instrument of establishing trust, which the study shows to increases farmers' participation in $\mathrm{CF}$ as well.

The study has also policy implications. Given that the larger the buyers' specific investment the higher the likelihood that they establish contracts with farmers. It can be concluded that any government initiative aiming to support contract farming should consider this category of intermediaries first. Thus, intermediaries ought to obtain a leadership role in the chain and policy makers may support trust building projects, which offer farmers and their buyers the opportunity to work together to build the value chain identity (i.e. fair distribution of value added, coordination, information sharing).

\section{References}

Arumugam N., Arshad F.M., Chiew E. and Mohamed M., 2011. Determinants of Fresh Fruits and Vegetables (FFV) Farmers' Participation in Contract Farming in Peninsular Malaysia. Journal of Agricultural Management and Development, 1(2), 65-71.

Bacharach S.B. and Lawler E.J., 1981. Power and tactics in bargaining. Industrial and Labor Relations Review, 34: 219-233.

Bagozzi R.P., Yi Y. and Phillips L.W., 1991. Assessing construct validity in organizational research. Administrative Science Quarterly, 36: 421-458. 
Bellemare M.F., 2012. As You Sow, So Shall You Reap: The Welfare Impacts of Contract Farming. World Development, 40(7): 1418-1434.

Bellemare M.F., 2018. Contract farming: opportunity cost and trade-offs. Agricultural Economics, 49(3): 279-288.

Bellemare M.F. and Novak L., 2017. Contract Farming and Food Security. American Journal of Agricultural Economics, 99(2): 357-378.

Benmehaia M.A. and Brabez F., 2018. Vertical Relationships and Food Supply Chain Coordination: The Case of Processing Tomato Sector in Algeria. New Medit, 17(2): 3-14.

Butaney G. and Wortzel L.H., 1988. Distributor power versus manufacturer power: the customer role. Journal of Marketing, 52: 52-63.

Coase R.H., 1937. The nature of the firm. Economica $N S, 4(16): 386-405$.

Collins A., 2002. The determinants of retailers' margin related bargaining power: evidence from the Irish food manufacturing industry. International Review of Retail, Distribution and Consumer Research, 12(2): 165-189.

Collins A., 2007. Retail Control of Manufacturers' Product-Related Activities: Evidence from the Irish Food Manufacturing Sector. Journal of Food Products Marketing, 13(2): 1-18.

David R.J. and Han S.-K., 2004. A systematic assessment of the empirical support for transaction cost economics. Strategic Management Journal, 25(1): 39-58.

El-Ansary A.I. and Stern L.W., 1972. Power measurement in the distribution. Journal of Marketing Research, 9(February): 47-52.

Etgar M., 1978. Selection of an effective channel control mix. Journal of Marketing, 42(July): 53-58.

FAO, 2013. Agrifood chain organization in Albaniathe case of MAPs and fruits. FAO.

Fernández-Olmos M. and Vinuesa L.M., 2009. Spot market versus incentive contract. New Medit, 8(3): 12-20.

Field A., 2009. Discovering Statistics Using SPSS (and sex and drugs and rock 'n' roll) ( $3^{\text {rd }} \mathrm{ed}$.). London: Sage.

Gaski J.F., 1986. Interrelations among a channel entity's power sources: Impact of the excercise of reward and coercion on expert, referent and legitimate power sources. Journal of Marketing Research, 23(February): 62-77.

Gaskin J., 2016. Exploratory Factor Analysis. Retrieved from Gaskination's StatWiki: http://statwiki.kolobkreations.com.
Gerdoci B., 2014. Governance of exchange relationships and its determinants. University of Tirana $\mathrm{PhD}$ Thesis.

Goldsmith A., 1985. The private sector and rural development: Can agribusiness help the small farmer? World Development, 13(10/11): 1125-1138.

Gow H.R., Streeter D.H. and Swinnen J.F., 2000. How Private Contract Enforcement Mechanisms Can Succeed Where Public Institutions Fail: The Case Of Juhocukor. Agricultural Economics, 23: 253-265.

Grosh B., 1994. Contract farming in Africa: An application of the new institutional economics. Journal of African Economies, 3(2): 231-261.

Hunt S.D. and Nevin J.R., 1974. Power in a channel of distribution: sources and consequences. Journal of Marketing Research, 11: 186-193.

INSTAT, 2016. Data related to production. Retrieved Novemeber 17, 2016, from http://www.instat.gov. $\mathrm{al} / \mathrm{al} /$ home.aspx.

Ito J., Bao Z. and Sun Q., 2012. Distributional Effects of Agricultural Cooperatives in China: Exclusion of Smallholders and Potential Gains on Participation. Food Policy, 37(6): 700-709.

Kaiser H., 1960. The application of electronic computers to factor analysis. Educational and Psychological Measurement, 20: 141-151.

Katchova A. and Miranda M., 2004. Two-Step Econometric Estimation of Farm Characteristics Affecting Marketing Contract Decisions. American Journal of Agricultural Economics, 86(1): 88-102.

Katsikeas C., Goode M.H. and Katsikea E., 2000. Sources of power in international marketing channels. Journal of Marketing Management, 16: 185202.

Key N. and Runsten D., 1999. Contract farming, smallholders, and rural development in Latin America. World Development, 27(2): 381-401.

Kirkwood J.B., 2005. Buyer Power and Exclusionary Conduct: Should Brooke Group Set the Standards for Buyer-Induced Price Discrimination and Predatory Bidding? Antitrust Law Journal, 72.

Klein B., 1996. Why Hold-Ups Occur: The Self-Enforcing Range of Contractual. Economic Inquiry, 34(3): 444-463.

Korovkin T., 1992. Peasants, Grapes, and Corporations: The Growth of Contract Farming in a Chilean Community. Journal of Peasant Studies, 19(2): 228-254.

Little P. and Watts M., 1994. Living under contract: Contract farming and agrarian transformation in Sub-Saharan Africa. Madison: University of Wisconsin Press. 
Lusch R.F. and Brown J.R., 1982. A Modified Model of Power in the Marketing Channel. Journal of Marketing Research, 16(August): 312-323.

Maertens M. and Swinnen J.F., 2009. Trade, standards, and poverty: Evidence from Senegal. World Development, 37(1): 161-178.

March J.G., 1955. An Introduction to the Theory and Measurement of Influence. American Political Science Review, 49(June): 433-451.

Masakure O. and Henson S., 2005. Why Do Small Scale Producers Choose to Produce under Contract? Lessons from Nontraditional Vegetable Exports from Zimbabwe. World Development, 33(10): 1721-1733.

Menard S., 1995. Applied logistic regression analysis. Sage university paper series on quantitative, 07-106. Thousand Oaks, CA: Sage.

Minot N., 2007. Contract farming in developing countries: patterns, impact, and policy implications. Case Study 6-3 of the Program, Food Policy for Developing Countries: the Role of Government in the Global Food System, Cornell University.

Miyata S., Minot N. and Hu D., 2009. Impact of contract farming on income: Linking small farmers, packers, and supermarkets in China. World Development, 37(11): 1728-1741.

Morgan R.M. and Hunt S.D., 1994. The Commitment-Trust Theory of Relationship Marketing. Journal of Marketing, 58(July): 20-38.

Nunally J.C., 1981. Psychometric Theory. New Delhi: McGraw-Hill.

Poppo L. and Zenger T., 2002. Do formal contracts and relational governance function as substitutes or complements? Strategic Management Journal, 23: 707-725.

Prowse M., 2012. Contract Farming in Developing Countries - A Review. France: Imprimerie de Montligeon.

Saqib S., Kuwornu J., Ali U. and Panezai S., 2018. Price risk management using forward contracts: the case of farmers in Pakistan. International Journal of Value Chain Management, 9(3): 241-256.

Sexton R., 2013. Market power, misconceptions, and modern agricultural markets. American Journal of Agricultural Economics (95): 209-219.

Shervani T.A., Frazier G. and Challagalla G., 2007. Moderating Effect of Firm Market Power on the Transaction Cost Economics Model: An empirical test in a forward channel integration context. Strategic Management Journal, 28: 635-652.

Simmons P., Winters P. and Patrick I., 2005. An Analysis of Contract Farming in East Java, Bali, and Lombok, Indonesia. Agricultural Economics, 33: 513-525.
Singh S., 2002. Contracting out solutions: Political economy of contract farming in the Indian Punjab. World Development, 30(9): 1621-1638.

Sivramkrishna S. and Jyotishi A., 2008. Monopsonistic exploitation in contract farming: Articulating a strategy for grower cooperation. Journal of International Development, 20(2): 280-296.

Skreli E., Imami D., Canavari M., Chan-Halbrendt C., Zhllima E. and Pire E., 2017. Assessing consumer preferences and willingness to pay for organic tomatoes in Albania: a choice experiment study. Spanish Journal of Agricultural Research, 15(3), pp. 1-13.

Sorrentino A., Russo C. and Cacchiarelli L., 2018. Market power and bargaining power in the EU food supply chain: the role of Producer Organizations. New Medit, 17(4): 21-31.

Stevens J., 2002. Applied multivariate statistics for the social sciences ( $4^{\text {th }}$ ed.). Hillsdale, NJ: Erlbaum.

Swinnen J., 2016. Economics and politics of food standards, trade, and development. Agricultural, Economics, 47: 7-19.

Ton G., Vellema W., Desiere S. and Weituschat S., 2018. Contract farming for improving smallholder incomes: What can we learn from effectiveness studies? World Development, 104: 46-64.

UNSTAT, 2016. Data related to international trade. Retrieved November 17, 2016, from https:// comtrade.un.org/.

Wang H., Wang Y. and Delgado M.S., 2014. The Transition to Modern Agriculture: Contract Farming in Developing Economies. American Journal of Agricultural Economics, 96(5): 1257-1271.

Weersink A. and Herath D., 2009. From plantations to smallholder production: The role of policy in the reorganization of the Sri Lankan tea sector. World Development: 1759-1772.

Williamson O.E., 1975. Markets and Hierarchies: Analysis and Antitrust Implications. New York: The Free Press.

Williamson O.E., 1981. The economics of organization: the transaction cost approach. American Journal of Sociology, 83: 539-577.

Xhoxhi O., Pedersen S.M., Lind K.M. and Yazar A., 2014. The Determinants of Intermediaries' Power over Farmers' Margin-Related Activities: Evidence from Adana, Turkey. World Development, 64: 815-827.

Zhu H. and Wang X., 2007. An Analysis on the Influencing Factors of Tomato Growers' Participation in Contract Farming in Xinjiang Autonomous Region. Chinese Rural Economy, 7: 67-75. 